Research Article

\title{
Study of epidemiological profile, clinico-biochemical spectrum and prognosis of malaria induced renal dysfunction in paediatrics age group
}

\author{
Suman Panwar*, Rajendra Kumar Soni, Nishat Ahmed
}

Department of Paediatrics, Sardar Patel Medical College, Bikaner, Rajasthan, India

Received: 14 August 2015

Accepted: 20 September 2015

\author{
*Correspondence: \\ Dr. Suman Panwar, \\ E-mail: sumimeghwal77@gmail.com
}

Copyright: () the author(s), publisher and licensee Medip Academy. This is an open-access article distributed under the terms of the Creative Commons Attribution Non-Commercial License, which permits unrestricted non-commercial use, distribution, and reproduction in any medium, provided the original work is properly cited.

\begin{abstract}
Background: Aim of current study was to assess the epidemiology, clinico-biochemical spectrum and prognosis of acute malaria induced nephropathy in children.

Methods: This was a prospective study conducted in the period from November 2013 to November 2014 in children suffering from acute malaria induced acute kidney injury. Malaria was confirmed by peripheral blood film or Rapid malaria test and detailed clinical evaluation and investigations were carried out to find multi-organ afflictions with special emphasis on renal involvement.

Results: Out of total 200 cases with malaria recorded in our hospital 60 (30\%) cases had acute malaria induced acute kidney injury caused by Plasmodium vivax in 45 (75\%), Plasmodium falciparum in 3 (5\%) and mixed infection in 12 $(20 \%)$ cases. Thirty percentage of cases had come from Sri Ganganagar district making it the most common geographical region in our study. The sex ratio was 3.6:1. Most common age group was 5-10 year age group contributing to $45 \%$ of the cases. Fever and oliguria being the most common presentation and was observed in all the cases followed by vomiting, pain abdomen and hypotension which was present in $33 \%, 32 \%$ and $20 \%$ of the cases respectively. Oliguria was present in all the cases in which $24(40 \%)$ cases had urine output $<1 \mathrm{ml} / \mathrm{kg} / \mathrm{hour}, 36(60 \%)$ patient had urine output $<0.5 \mathrm{ml} / \mathrm{kg} /$ hour with G.F.R $>25 \mathrm{ml} / \mathrm{min} / 1.73 \mathrm{~m}^{2}$ and $<25 \mathrm{ml} / \mathrm{min} / 1.73 \mathrm{~m}^{2}$ seen in $40(66 \%)$ and $3(5 \%)$ cases respectively. Fifty five patients $(91.66 \%)$ had S. creatinine between $1.5-3 \mathrm{mg} / \mathrm{dl}$ and only 5 patients $(8.33 \%)$ had serum creatinine $>3 \mathrm{mg} / \mathrm{dl}$. $75 \%$ cases recovered in $<5$ days and 4 patients expired, 2 due to respiratory failure and 2 due to MODS and cerebral malaria. expired cases two were died due to respiratory failure, other two were died due to multiorgan failure and cerebral malaria.

Conclusions: The spectrum of renal involvement due to malaria is variable ranging from mild derangement of renal functions to advanced stage of renal dysfunction which needs immediate dialysis. Severe renal involvement was mainly seen with $P$. falciparum but in our study it is mainly seen with $P$. vivax infection.
\end{abstract}

Keywords: Acute renal failure, Plasmodium vivax, Plasmodium falciparum, Malarial acute kidney injury, Malaria induced acute kidney injury

\section{INTRODUCTION}

Malaria remains a serious health problem in many parts of the world. It causes high morbidity and claims many lives in developing countries each year. Humans are generally infected by four species of malaria parasites. ${ }^{1}$ Malarial acute kidney injury is commonly found in non- immune adults and older children with falciparum malaria and occasionally with Plasmodium vivax. Occurrence of malaria induced acute kidney injury in severe falciparum malaria is quite common in Southeast Asia and Indian subcontinent where intensity of malaria transmission is usually low. ${ }^{2}$ Major manifestations of severe malaria in children are cerebral malaria, severe 
anemia, metabolic acidosis and renal failure. ${ }^{3,4}$ Although there are studies describing the association of Malaria induced acute kidney injury in adults, very few have been reported in children. ${ }^{5-7}$ Acute renal failure is a syndrome characterized by rapid decline in glomerular filtration rate in hours to week and retention of nitrogenous waste products such as blood urea nitrogen and creatinine. ${ }^{8}$ Acute renal failure commonly occurs in Plasmodium falciparum malaria and its incidence ranges between 4 $17.2 \%$ and it may reach upto $60 \%$ in cases with severe infection. $^{9}$ Although, its rare occurrence has been reported in $P$. vivax infection also. ${ }^{10-12}$

\section{METHODS}

A prospective review of data for all children admitted into the Department of Paediatrics, Sardar Patel Medical College Bikaner, with the diagnosis malaria and acute renal failure over a period (November 2013 to November 2014) was performed. After admission Data of the cases including name, address age, sex, clinical features, blood pressure, laboratory and radiological investigations like full blood count, thick and thin blood film for malaria parasite, serum electrolytes, blood urea nitrogen and creatinine, urinalysis, urine microscopy, culture and sensitivity, ultrasonography and information regarding the treatment received including antimalarial was noted in a predefined performa are done.

Other medical causes leading to acute kidney injury like sepsis, infections causing multiorgan dysfunction likes enteric fever, brucellosis, leptospirosis, hepatitis A, hepatitis B, hepatitis $\mathrm{C}$, hepatitis $\mathrm{E}$ and dengue were ruled out by relevant tests. Patients with past history of systemic illness which affects the renal function tests were also excluded from our study. 60 children who met the definition of malaria induced acute kidney injury were included in the study.

Malaria induced acute kidney injury was determined if there were deranged renal function tests i.e.; serum creatinine $>1.5 \mathrm{mg} / \mathrm{dl}$ and urine output $<1 \mathrm{ml} / \mathrm{kg} /$ hour. All the patients were treated according to National Vector Borne Disease Control Programme guidelines. ${ }^{13}$

Ethics: A written ethical clearance was taken from the ethical committee of the college and written consent was taken from patient's parents/guardian.

Statistics: Statistical mean \pm SD were compared using Student $t$ test; where indicated, chi-square and Fisher exact tests were carried out to compare proportions for statistical significance. Values of $\mathrm{P}<0.05$ was regarded as statistically significant. The $95 \%$ confidence interval (CI) was determined from Miettinen's test-based approximation using the chi-square [95\% CI = OR $(1 \pm 1$ . 96/X) (16)], 1.96 being the 5\% point of the standard normal distribution, $\mathrm{X}=\mathrm{X}^{2}$.

\section{RESULTS}

All the cases diagnosed as malaria induced acute kidney injury were included in the study. Forty five (75\%) patients had $P$. vivax malaria, 3 patients $(5 \%)$ had $P$. falciparum malaria and mixed infection $(P$. vivax $+P$. falciparum) was present in $12(20 \%)$ cases. Maximum cases $18(30 \%)$ were belonged to Sri Ganganagar district contributed to the maximum number of the cases i.e. $18(30 \%)$ in our study followed by $17(28.33 \%)$ cases to Bikaner district including (Nokha, Kolayat, Khajuwala). Sex ratio was 3.6:1 which statisticaly significant for $P$. vivax malaria with $\mathrm{P}$ value $<0.0001$ for both sexes. The patients were aged 5 days to 16 years and we found 27 (45\%) patients presenting with malaria induced acute renal failure were in the 5-10 year age group. Fever and oliguria were observed in all the patients followed by vomiting and hypotension in $33 \%, 20 \%$ cases respectively. Hepatosplenomegaly was observed in $32 \%$ cases. Electrolyte abnormalities were found in $36(60 \%)$ patients in which hyponateremia, hypokalemia, hyperkalemia, hypernatremia was seen in $33.33 \%$, $16.66 \%$, 5\% cases respectively $40 \%$ and $60 \%$ patients had urine output $<1 \mathrm{ml} / \mathrm{kg} /$ hour and $<0.5 \mathrm{ml} / \mathrm{kg} /$ hour respectively which statistically significant for $P$. vivax malaria with $\mathrm{P}$ value $<0.0001$ because $31(68 \%)$ patients out of 45 cases of $P$. vivax malaria had urine output $<0.5$ $\mathrm{ml} / \mathrm{kg}$ /hour. G.F.R $>25 \mathrm{ml} / \mathrm{min} / 1.73 \mathrm{~m}^{2}$ and $<25$ $\mathrm{ml} / \mathrm{min} / 1.73 \mathrm{~m}^{2}$ seen in $66 \%$ and $5 \%$ cases respectively which statistically significant for $P$. vivax malaria with $\mathrm{p}$ value $<0.0001$ because $30(66 \%)$ patients out of 45 cases of $P$. vivax malaria had G.F.R $>25 \mathrm{ml} / \mathrm{min} / 1.73 \mathrm{~m}^{2}$. S. creatinine $>3 \mathrm{mg} / \mathrm{dl}$ and $1.5-3 \mathrm{mg} / \mathrm{dl}$ seen in $8.33 \%$ and $91.66 \%$ cases respectively which is statistically significant for $P$. vivax malaria and mixed infection $(P$. vivax+ $P$. falciparum) cases with $\mathrm{P}$ value $<0.0001$ because $S$. creatinine $1.5-3 \mathrm{mg} / \mathrm{dl}$ seen in $41(91 \%)$ out of total 45 cases of $P$. vivax and $12(100 \%)$ cases out 12 cases of mixed infection ( $P$. vivax+ $P$. falciparum). $75 \%$ cases recovered in $<5$ days, out of 4 expired cases two were died due to respiratory failure, other two were died due to multiorgan failure and cerebral malaria. After approval from ethical committee and written consent of patient and patient's relative, all patients were treated as per WHO guideline. All patients were treated with either artesunate $2.4 \mathrm{mg} / \mathrm{kg}$ over 10 minutes followed by 2.4 $\mathrm{mg} / \mathrm{kg}$ after 12 hours of 1 dose \& then $2.4 \mathrm{mg} / \mathrm{kg}$ every 24 hours i.v or switch off to oral as per patient oral acceptance or i.v quinine $20 \mathrm{mg} / \mathrm{kg}$ loading dose over 4 hours in D-10\% then $10 \mathrm{mg} / \mathrm{kg}$ at 8 hourly for a total of 7 days of therapy. Dose reduction was done as required for deranged renal functions. Fluids were given according to urine output. Blood transfusion were given to patients with $\mathrm{Hb}<5 \mathrm{gm} / \mathrm{dl}$ or those with bleeding manifestations. Patients were subjected to hemodialysis when oliguria persisted or deteriorated, there were signs of fluid overload, or there was rapid serial rise in serum creatinine $\&$ there were no contradictions to hemodialysis. All of patients were followed during the course of their illness. 
Table 1: Major clinical manifestations in malaria induced acute renal failure patients.

\begin{tabular}{|ll|}
\hline Manifestation & Total \\
\hline Fever & $60 / 60$ \\
\hline Vomiting & $32 / 60$ \\
\hline Unconsciousness & $7 / 60$ \\
\hline Convulsions & $8 / 60$ \\
\hline Oligo/Anuria & $56 / 60$ \\
\hline Abdomen pain & $9 / 60$ \\
\hline Dyspnea & $6 / 60$ \\
\hline Hypotension & $20 / 60$ \\
\hline Headache & $8 / 60$ \\
\hline Jaundice & $4 / 60$ \\
\hline Hepatosplenomegaly & $33 / 60$ \\
\hline
\end{tabular}

Table 2: Electrolyte abnormalities in patients of malaria induced acute renal failure.

\begin{tabular}{|c|c|c|c|c|}
\hline \multirow[b]{2}{*}{$\begin{array}{l}\text { Malaria } \\
\text { species }\end{array}$} & \multicolumn{4}{|c|}{ Electrolyte abnormality } \\
\hline & $\begin{array}{l}\text { Hypo- } \\
\text { kalemia } \\
<3.5 \\
\mathrm{mg} / \mathrm{dl}\end{array}$ & $\begin{array}{l}\text { Hyper- } \\
\text { kalemia } \\
>5.5 \\
\mathrm{mg} / \mathrm{dl}\end{array}$ & $\begin{array}{l}\text { Hypo- } \\
\text { natremia } \\
<135 \\
\text { mg/dl }\end{array}$ & $\begin{array}{l}\text { Hyper- } \\
\text { natremia } \\
>145 \\
\mathrm{mg} / \mathrm{dl}\end{array}$ \\
\hline $\begin{array}{l}\text { P. vivax } \\
\text { (P.V.) }\end{array}$ & 8 & 2 & 12 & 3 \\
\hline $\begin{array}{l}\text { P. falciparum } \\
\text { (P.F.) }\end{array}$ & 0 & 0 & 3 & 0 \\
\hline Mixed & 2 & 1 & 5 & 0 \\
\hline Total & 10 & 3 & 20 & 3 \\
\hline
\end{tabular}

Table 3: Malaria induced acute renal failure $\&$ relationship of urine output.

\begin{tabular}{|lll|}
\hline $\begin{array}{l}\text { Malaria } \\
\text { species }\end{array}$ & $\begin{array}{l}\text { Urine output } \\
\mathbf{0 . 5 - 1} \mathbf{~ m l} / \mathbf{k g} / \mathbf{h o u r}\end{array}$ & $\mathbf{< 0 . 5} \mathbf{~ m l} / \mathbf{k g} / \mathbf{h o u r}$ \\
\hline $\begin{array}{l}\text { P. vivax (P.V.) } \\
\text { P.falciparum }\end{array}$ & 14 & 31 \\
\hline $\begin{array}{l}\text { (P.F.) } \\
\text { Mixed }\end{array}$ & 9 & 2 \\
\hline Total & $24(40 \%)$ & 3 \\
\hline
\end{tabular}

Table 4: Malaria induced acute renal failure \& G.F.R. relation.

\begin{tabular}{|c|c|c|}
\hline \multirow{2}{*}{$\begin{array}{l}\text { Malaria } \\
\text { species }\end{array}$} & \multicolumn{2}{|c|}{ G.F.R. $\mathrm{ml} / \mathrm{min} / 1.73 \mathrm{~m}^{2}$} \\
\hline & $<25 \mathrm{ml} / \mathrm{min} / 1.73 \mathrm{~m}^{2}$ & $>25 \mathrm{ml} / \mathrm{min} / 1.73 \mathrm{~m}^{2}$ \\
\hline $\begin{array}{l}\text { P. vivax } \\
\text { (P.V.) }\end{array}$ & 12 & 33 \\
\hline $\begin{array}{l}\text { P. falciparum } \\
\text { (P.F.) }\end{array}$ & 3 & 0 \\
\hline Mixed & 5 & 7 \\
\hline Total & $20(33 \%)$ & $40(66 \%)$ \\
\hline
\end{tabular}

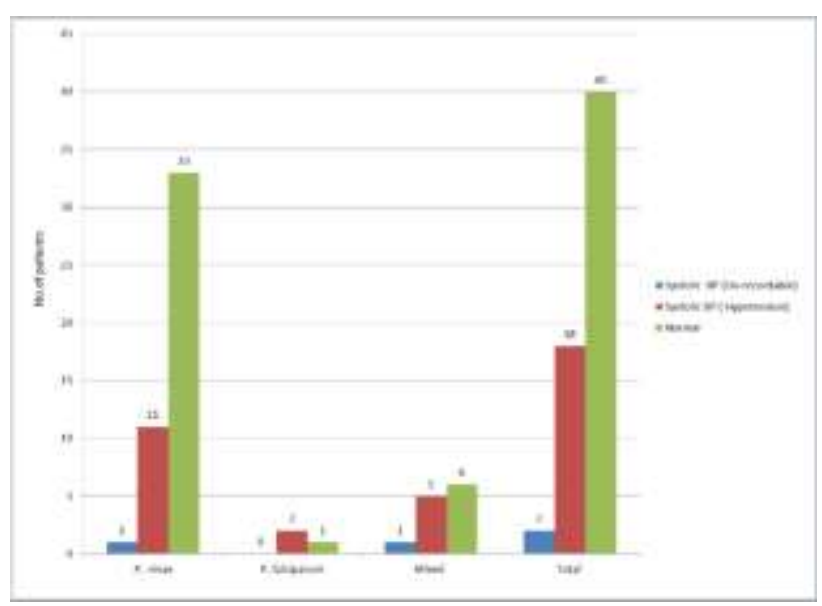

Figure 1: Systolic blood pressure in malaria induced ARF patients.

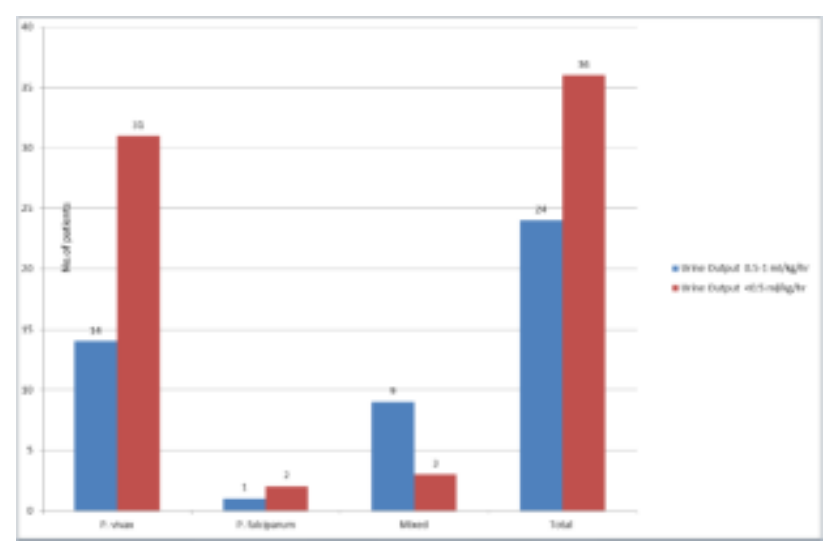

Figure 2: Relation of urine output in malaria induced ARF patients.

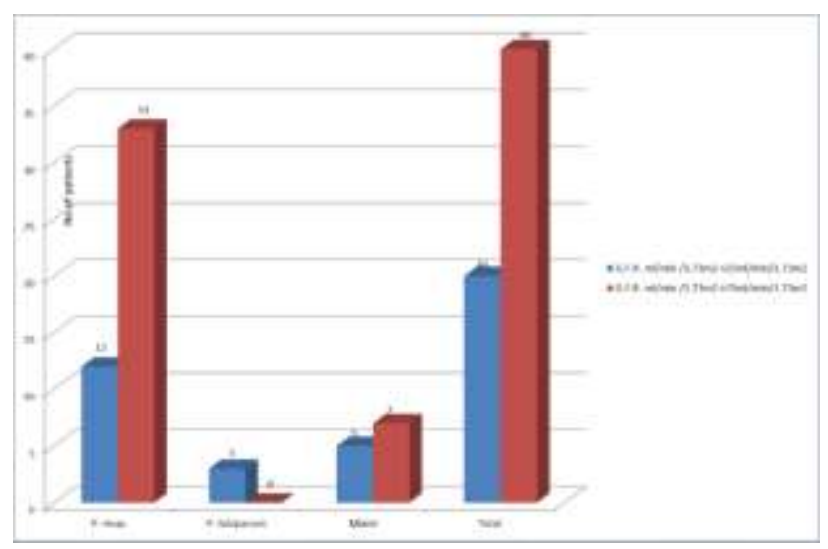

Figure 3: G.F.R. relation in malaria induced ARF patients.

\section{DISCUSSION}

Desert area of Rajasthan including the Bikaner district has been hypoendemic for malaria with some pockets of existence of $P$. falciparum. With a spurt in developmental activities in this area over the last decade, global climatic changes, increased irrigation activities due to Indira 
Gandhi canal project, increased influx of laborers from the eastern part of country and massive deployment of armed forces and unprecedented rains have caused marked changes in the epidemiological and clinical profile of malaria in this region. Over the last years jaundice and acute renal failure are increasingly being noticed in patients of malaria. Although renal dysfunction has invariably been reported in $P$. falciparum malaria but its association with $P$. vivax malaria is also being noticed. ${ }^{14}$ In India about $70 \%$ of the infection are reported to be due to $P$. vivax, 25-30\% due to $P$. falciparum and 4$8 \%$ due to mixed infection. Malarial acute kidney dysfunction's lower incidence among 0-5 year may be due to maternal immunity in infants and more care and attention given by parents to the young children. Higher incidence among the age group 5-10 year is due to more mobility and unaware about preventive aspect of the disease. Sex ratio of our study is 3.6:1 which correlated with study of Mehta et al who reported Male:Female ratio of 2.04 in their study. Thus they found that males were predisposed to develop more renal dysfunction than females and our study also found similar pattern. ${ }^{14}$ Fever and oliguria were observed in all the patients (100\%) followed by HSM and vomiting in 33\% \& $32 \%$ respectively. Hypotension was observed in $20 \%$ of patients. In a study conducted at tertiary care center at Asarwa, Ahmadabad, Gujarat, India the presenting features were fever $(100 \%)$, nausea-vomiting (89\%), oligo/anuria (82\%), abdominal pain/tenderness (55\%), jaundice $(55 \%)$, dyspnea $(30 \%)$, altered sensorium (31\%), convulsions (18\%), diarrhea (17\%), Splenomegaly (69\%) and hepatomegaly (39\%), which nearly have similar finding. ${ }^{15}$ Stone et al. has also reported oliguric renal failure in 36 out of $42(85.71 \%)$ patients and only $6(14.28 \%)$ were non oliguric. ${ }^{16}$ Creatinine $>3 \mathrm{mg} / \mathrm{dl}$ was observed in $5(8.33 \%)$ patients and $55(91.66 \%)$ had S. creatinine level $<3 \mathrm{mg} / \mathrm{dl}$ which found to be statistically significant. A Study done by Saroj et al. found similar findings. ${ }^{17}$

Stone et al also found that average duration of symptoms after hospitalization was eight days. ${ }^{16}$ William $\mathrm{J}$ stone et al found that mortality was $29 \%$ in patients of $P$. falciparum malaria with renal failure and the major causes of mortality were cerebral and pulmonary complication. These finding are identical to those of our study. The overall mortality in our study of patient with malarial induced renal dysfunction was $6.66 \%$. Causes of death were found to be multifactorial. However prognosis was grave when multi organ system was involved and pulmonary edema develops. In the present study multi organ system involvement and development of pulmonary edema was found to be the commonest cause of death. Sitpriza et al. in their study of 163 malarial patients found the major causes of mortality were multiorgan failure in $12(57.14 \%)$, pulmonary edema in 6 (28.57\%), ARDS in $2(9.52 \%)$ and massive GI bleed one patient. ${ }^{18}$ This supports our study.
Major limitation of our study is limited sample size and under reporting of cases which goes unrecognized and under reporting.

But by doing following study we can able to recognize that as early as patient report to hospital many life can be saving by doing appropriate investigation and early started treatment can help to early recovery of patients.

Funding: No funding sources

Conflict of interest: None declared

Ethical approval: The study was approved by the institutional ethics committee

\section{REFERENCES}

1. Elsheikha HM, Sheashaa HA. Epidemiology, Pathophysiology, management and outcome of renal dysfunction associated with plasmodia infection. Parasitol Res. 2007;101:1183-90.

2. Das BS. Renal failure in malaria. J Vector Borne Dis. 2008;45:83-97.

3. Trampuz A, Jereb M, Muzlovic I, Prabhu RM. Clinical review: severe malaria. Crit Care. 2003;7:315-23.

4. Nand N, Aggrawal H, Sharma M, Singh $M$. Systemic manifestations of malaria. J Indian Acad Clin Med. 2001;2:189-94.

5. Brewster DR, Greenwood BM. Seasonal variation of pediatric diseases in the Gambia, West Africa. Ann Trop Paediatr. 1993;13:133-46.

6. Sharma AK, Arora M, Gupta H, Gupta R. Malarial acute renal failure in Rajasthan. J Assoc Physicians India. 1998;46:1001-2.

7. Mehta KS, Halankar AR, Makwana PD, Torane PP, Satija PS, Shah VB. Severe acute renal failure in malaria. J Postgrad Med. 2001;47:24-6.

8. Brady HR, Brenner BM, Clarkson MR, Leiberthal W. Acute renal failure. In: Barry M, Brenner, eds. The Kidney. 6th ed. Philadelphia: WB Saunders Co; 2000: 1201.

9. Mahakur AC, Panda SN, Nanda BK, Bose TK, Satapathy SR, Misra Y. Malarial acute renal failure. J Assoc Physicians India. 1983 Oct;31(10):633-66.

10. Sheehy TW, Reba RC. Complications of falciparum malaria their treatment. Ann Int Med. 1967;66:8079.

11. Nand N, Aggarwal H, Sharma M, Singh M. Systemic manifestation of malaria. J Indian Acad Clin Med. 2001;2:189-94.

12. Kumar S, Epstein JE, Richie TL. Vaccines agonist asexual stage malaria parasites. Chem Immunol. 2002;80:282-6.

13. Tripathy R, Parida S, Das L, Mishra DP, Tripathy $\mathrm{D}$, Das MC, et al. Clinical manifestations and predictors of severe malaria in Indian children. Pediatrics. 2007;120:e454-60.

14. Mehta KS, Halankar AR, Satija PS, Torne PP, Panchal PD, Saha VB, et al. Severe acute renal failure in malaria. South Asian Nephrology 
Congress and International CME. New Delhi: Scientific Proceedings; 2000: 22.

15. Kanodia KV, Shah PR, Vanikar AV, Kasat P, Gumber M, Trivedi HL. Malaria induced acute renal failure: a single centre experience. Saudi J Kidney Dis Transplant. 2010;21(6):1088-91.

16. Stone WJ, Hanchett JE, Knepshield JH. Acute renal insufficiency due to falciparum malaria. Review of 42 cases. Arch Intern Med. 1972;129(4):620-8.

17. Mishra SK, Mohapatra S, Mohanty S, Patel NC, Mohapatra DN. Acute renal failure in falciparum malaria. J Indian Acad Clin Med. 2002;3(2):141-7.
18. Sitprija V, Indraprasit S, Pochanugool C, Benyajati C, Piyaratn P. Renal failure in malaria. Lancet. 1967;1(7483):185-8.

Cite this article as: Panwar S, Soni RK, Ahmed N. Study of epidemiological profile, clinico-biochemical spectrum and prognosis of malaria induced renal dysfunction in paediatrics age group. Int J Contemp Pediatr 2016;3:91-5. 